\title{
Multiple genus-specific markers in PCR assays improve the specificity and sensitivity of diagnosis of brucellosis in field animals
}

\author{
Correspondence \\ Mrinalini Nair \\ mnair@msubiotech.ac.in \\ or \\ mnair_in@yahoo.com
}

Received 9 January 2007

Accepted 18 April 2007

\author{
Falguni Mukherjee, ${ }^{1}$ Jainendra Jain, ${ }^{1}$ Vipul Patel ${ }^{1}$ and Mrinalini Nair ${ }^{2}$ \\ ${ }^{1}$ Research and Development, National Dairy Development Board, Anand 388 001, Gujarat, India \\ ${ }^{2}$ Biotechnology Program, Department of Microbiology and Biotechnology Centre, MS University, \\ Baroda 390002, Gujarat, India
}

Brucella-specific nucleotide sequences encoding the BCSP $31 \mathrm{kDa}$ protein, Omp2 and the 16S rRNA were employed in three independent diagnostic PCR assays. Results of the three PCR assays on six reference strains of Brucella were in complete agreement. The results of PCR assays based on bcsp and omp2 on 19 Indian field isolates (human, bovine and murine tissues) also agreed completely. However, when the 16S rRNA gene was employed as the diagnostic target in the PCR, only 14 out of these 19 isolates and 2 out of 7 bovine milk isolates were identified as the genus Brucella. The bovine blood samples were insensitive to 16S rRNA PCR. The antibody-detecting ELISA results of field samples $(n=87)$ from a serologically positive herd in India were compared separately with omp2 and bcsp PCRs of blood $(n=62)$. While the bcsp PCR was the most sensitive, the degree of association of ELISA with omp2 blood PCR $(\kappa=0.37$ at $P<0.05)$ was similar to that with the bcsp blood PCR $(\kappa=0.34$ at $P<0.05)$. An improvement in the correlation between ELISA and blood PCR was noticed $(\kappa=0.5$ at $P<0.05)$ when a consensus result of omp2 and bcsp blood PCR was considered for comparison with ELISA. The use of more than one marker-based PCR gave increased sensitivity and higher specificity and appears to be a more reliable molecular diagnostic approach for screening of field animals.

\section{INTRODUCTION}

Brucellosis causes infertility and abortion in bovines (Radostits et al., 1994; Corbel, 1997) and undulant fever in humans (Corbel \& Brinley-Morgan, 1984). Bovine brucellosis is usually caused by Brucella abortus, and less frequently by Brucella melitensis and Brucella suis (OIE, 1996). Among the six recognized species of Brucella, $B$. abortus, B. melitensis, B. suis and Brucella canis can potentially infect humans (Nicoletti, 1980) while Brucella ovis and Brucella neotomae have not been isolated from humans.

Accurate diagnosis of brucellosis requires bacteriological isolation and detection of the pathogen in the laboratory, which is impractical for regular screening of large populations (Alton et al., 1988; Lulu et al., 1988; Radostits et al., 1994; Yagupsky, 1994). Serological tests can be nonspecific owing to cross-reaction or subsensitive or high immunity reactions, depending on subclinical or endemic prevalence of the disease (Ariza et al., 1992; Weynants et al., 1996; Godfroid et al., 2002). Numerous

Abbreviation: OPA, overall proportion of agreement.
PCR-based assays have been developed for the identification of the genus Brucella from cultures, animal/human tissues and animal products. These employ the gene encoding the $31 \mathrm{kDa}$ Brucella cell surface salt extractable protein (BCSP), omp2, 16S rRNA, IS711 and other gene targets (Baily et al., 1992; Leal-Klevezas et al., 1995; Da Costa et al., 1996; Rijpens et al., 1996; Bricker, 2002; Morata et al., 2003; Bogdanovich et al., 2004; Mukherjee et al., 2005; O'Leary et al., 2006). Real-time PCRs for high sensitivity detection (Redkar et al., 2001; Probert et al., 2004; Navarro et al., 2006; Queipo-Ortuno et al., 2005) and differential/multiplex PCRs for strain typing based on locus-specific variations (Ewalt \& Bricker, 2000; Bardenstein et al., 2002; Probert et al., 2004; Mukherjee et al., 2005; Ferrao-Beck et al., 2006; Marianelli et al., 2006) or variable tandem repeats (Bricker \& Ewalt, 2006; Le Fleche et al., 2006) of Brucella isolates have been reported.

For large-scale field screening, identification of Brucella by genus-specific PCR tends to be simple and adequate. The diagnostic PCRs so far employed in field animals for direct screening (Fekete et al., 1992; Leal-Klevezas et al., 1995; Amin et al., 2001; Leyla et al., 2003; O'Leary et al., 2006) and comparative evaluation against serology (Romero et al., 
1995b; Sreevatsan et al., 2000) or isolation have relied on single gene targets. The sensitivity and specificity of diagnostic assays can influence effective prevention and control of zoonoses as well as aid in selection of animals for breeding, etc. There are few comparative studies on the specificity of the different genus-specific PCRs and their correlation with serological diagnosis. This study analyses the sensitivity and specificity of the three established genusspecific PCRs of $b c s p$, omp2 and $16 \mathrm{~S}$ rRNA gene sequences, and further evaluates their comparative efficiencies for the simple detection of the genus Brucella directly from blood samples, in a large-scale screening of individual animals from serologically positive Indian field buffaloes/ cattle herds. Further, a correlation between the diagnostic specificities of PCRs and an antibody-detecting blood ELISA is assessed employing kappa statistics.

\section{METHODS}

Brucella isolates and blood samples. Brucella strains were isolated from experimentally infected murines $(n=2)$, field isolates of human blood $(n=4)$ and bovine milk $(n=7)$ and uterine discharge $(n=6)$. Bovine blood samples $(n=87)$ used for serology and PCR studies were from two serologically positive herds of western India.

Source and maintenance of strains. The details of the origin of the standard strains are given in Table 1. Brucella reference and field strains were identified and maintained as per the standard protocols (Alton et al., 1988). Escherichia coli ATCC 3616 was propagated on nutrient agar at $37{ }^{\circ} \mathrm{C}$; Yersinia enterocolitica $\mathrm{O}: 3$ and $\mathrm{O}: 9$ were maintained on brain heart infusion agar (HI Media) at $28{ }^{\circ} \mathrm{C}$; and Vibrio cholerae O:1 Inaba and Ogawa strains were grown on Terrestrial Yeast Extract medium at $25{ }^{\circ} \mathrm{C}$ (Baumann et al., 1984). Mycobacterium tuberculosis H37Rv (ATCC 25618) was maintained on glycerol-supplemented Löwenstein-Jensen medium according to the ATCC Catalogue of Bacteria and Bacteriophages.

Table 1. Bacterial strains studied by three Brucella-specific PCRs

\begin{tabular}{|c|c|c|c|c|}
\hline \multirow[t]{2}{*}{ Bacterial strains studied } & \multirow[t]{2}{*}{ Source ${ }^{*}$} & \multicolumn{3}{|c|}{ PCR results } \\
\hline & & BCSP $31 \mathrm{kDa}$ & $o m p 2$ & 16S rRNA \\
\hline Brucella abortus 544 (23448) & ATCC & + & + & + \\
\hline Brucella melitensis $16 \mathrm{M}$ (23546) & ATCC & + & + & + \\
\hline Brucella ovis $63 / 290$ & ATCC & + & + & + \\
\hline Brucella suis 1330 & IVRI & + & + & + \\
\hline Brucella canis & IVRI & + & + & + \\
\hline Brucella neotomae (2359) & ATCC & + & + & + \\
\hline Yersinia enterocolitica $\mathrm{O}: 3$ & HAU & - & - & - \\
\hline Yersinia enterocolitica $\mathrm{O}: 9$ & HAU & - & - & - \\
\hline Vibrio cholerae Inaba & NICE & - & - & - \\
\hline Vibrio cholerae Ogawa & NICE & - & - & - \\
\hline Escherichia coli (3616) & ATCC & - & - & - \\
\hline Mycobacterium tuberculosis H37Rv (25618) & ATCC & - & - & - \\
\hline B. melitensis $3 / 97$ cattle uterine discharge & IVRI & + & + & + \\
\hline B. melitensis 5/97 cattle uterine discharge & IVRI & + & + & + \\
\hline B. melitensis $7 / 97$ cattle uterine discharge & IVRI & + & + & + \\
\hline B. melitensis $20 / 97$ human male blood & IVRI & + & + & + \\
\hline B. melitensis $24 / 97$ human female blood & IVRI & + & + & + \\
\hline B. melitensis $25 / 97$ human male blood & IVRI & + & + & + \\
\hline B. melitensis $5 / 98$ human female blood & IVRI & + & + & + \\
\hline B. abortus $\left(\mathrm{CO}_{2}\right.$-dependent $) 10 / 98$ cattle vaginal swab & IVRI & + & + & + \\
\hline B. abortus $\left(\mathrm{CO}_{2}\right.$-dependent) $18 / 98$ cattle uterine discharge & IVRI & + & + & + \\
\hline B. abortus $86 / 6$ cattle uterine discharge & IVRI & + & + & + \\
\hline B. abortus 544 (ATCC) infected murine genital tissue & NDDB & + & + & + \\
\hline B. abortus S19 (IVRI) infected liver & NDDB & + & + & + \\
\hline Brucella sp. MI 4 bovine milk isolate & NDDB & + & + & - \\
\hline Brucella sp. MI 19 bovine milk isolate & NDDB & + & + & - \\
\hline Brucella sp. MI 22 bovine milk isolate & NDDB & + & + & + \\
\hline Brucella sp.MI 23 bovine milk isolate & NDDB & + & + & - \\
\hline Brucella sp. MI 42 bovine milk isolate & NDDB & + & + & - \\
\hline Brucella sp. MI 43 bovine milk isolate & NDDB & + & + & - \\
\hline Brucella sp. MI 46 bovine milk isolate & NDDB & + & + & - \\
\hline
\end{tabular}

${ }^{\star}$ ATCC, American type Culture Collection, USA; IVRI, Indian Veterinary Research Institute, Izatnagar, India; HAU, Haryana Agricultural University, Hisar, India; NICE, National Institute of Cholera and Enteric Diseases, Kolkata, India; NDDB, Research \& Development, National Dairy Development Board, Anand, India. 
ELISA. An indirect Brucella antibody detection avidin-biotin ELISA (Animal Disease Monitoring and Surveillance, Indian Council for Agricultural Research, Bangalore, India) was used to assess the serological status of the two herds.

Extraction of genomic DNA from bacteria. Brucella grown for $72 \mathrm{~h}$ was washed twice in PBS ( $\mathrm{pH}$ 6.4), pelleted by centrifugation at $3000 \mathrm{~g}$ for $20 \mathrm{~min}$ and suspended in $500 \mu \mathrm{l}$ Tris/EDTA (pH 8.0). For the other bacteria except M. tuberculosis H37Rv (ATCC 25618), 24 $48 \mathrm{~h}$ cultures were washed in PBS. The suspension was subjected to three cycles of snap freezing at $-196{ }^{\circ} \mathrm{C}$ in liquid nitrogen and boiling at $95{ }^{\circ} \mathrm{C}$ for $10 \mathrm{~min}$ to obtain crude cell lysates. The lysates were sequentially treated with lysozyme $\left(1 \mathrm{mg} \mathrm{ml}^{-1}\right)$ at $37{ }^{\circ} \mathrm{C}$ for $1 \mathrm{~h}$, proteinase $\mathrm{K}\left(1 \mathrm{mg} \mathrm{ml}^{-1}\right)$ and sodium dodecyl sulfate $(1 \%)$ at $50{ }^{\circ} \mathrm{C}$. The lysates were subsequently extracted with standard phenol/ chloroform, and the genomic DNA was precipitated, dried, suspended in $50 \mu \mathrm{l} \mathrm{TE}$ and stored at $-20{ }^{\circ} \mathrm{C}$.

DNA was extracted from 3-4-week-old cultures of M. tuberculosis H37Rv according to a previously described protocol (Cousins et al., 1993).

Extraction of DNA from blood samples. DNA was extracted from bovine blood samples using a slight modification of a protocol published by Leal-Klevezas et al. (1995). Heparinized blood $(500 \mu \mathrm{l})$ was centrifuged at $1500 \mathrm{~g}$ for $3 \mathrm{~min}$. Cell pellets were suspended in erythrocyte lysis buffer (155 mM ammonium chloride, $10 \mathrm{mM}$ sodium bicarbonate, $100 \mathrm{mM}$ disodium EDTA, pH 7.4) and centrifuged at $1500 \mathrm{~g}$ for $3 \mathrm{~min}$; the cycle was repeated two to three times until the red colour due to the erythrocytes was minimal. The pellet was then treated with leukocyte lysis buffer ( $2 \%$ Triton X-100, $1 \%$ sodium dodecyl sulfate, $100 \mathrm{mM} \mathrm{NaCl}, 10 \mathrm{mM}$ Tris/HCl, $\mathrm{pH} 8.0$ ), centrifuged at $3000 \mathrm{~g}$ for $5 \mathrm{~min}$ and the pellet was digested with $10 \mu$ l proteinase $\mathrm{K}\left(10 \mathrm{mg} \mathrm{ml}^{-1}\right)$ for $40 \mathrm{~min}$ at $50{ }^{\circ} \mathrm{C}$. Following enzymic digestion, the samples were extracted with phenol/chloroform and processed as above

PCR assays. Three genus-specific PCR assays were performed for the identification of Brucella. (i) The PCR for the genus-specific Brucella cell surface salt extractable (BCSP) $31 \mathrm{kDa}$ protein gene (Bricker et al., 1988; Mayfield et al., 1988) was performed on bacterial lysates and DNA extracts of isolates from experimentally infected mouse spleen, bovine blood and milk isolate samples, employing forward primer B4 (5' TGG CTC GGT TGC CAA TAT CAA $3^{\prime}$ ) and reverse primer B5 (5' CGC GCT TGC CTT TCA GGT CTG $3^{\prime}$ ) as described by Baily et al. (1992). (ii) The omp2 gene (GenBank accession no. M26034) (Fitch et al., 1989) was amplified from reference and field strains of Brucella in a $25 \mu \mathrm{l}$ reaction mixture using primers JPF (5' GCG CTC AGG CTG CCG ACG CAA 3') and JPR (5' ACC AGC CAT TGC GGT CGG TA $3^{\prime}$ ) as per Leal-Klevezas et al. (1995). However, for amplification of DNA from field blood samples, the above protocol was modified by using $100 \mathrm{pmol}$ of each primer and $4 \mathrm{mM} \mathrm{Mg}^{2+}$ in the PCR. (iii) The 16S rRNA gene (EMBL accession no. X13695) (Dorsch et al., 1989) was amplified from reference and field strains of Brucella by modifying the PCR protocol of Romero et al. (1995b). The PCR employed $0.5 \mu \mathrm{M}$ each of a forward F4 (5' TCG AGC GCC CGC AAG GG $3^{\prime}$ ) and a reverse R2 (5' AAC CAT AGT GTC TCC ACT AA $3^{\prime}$ ) primer (Romero et al., 1995a). The $25 \mu \mathrm{l}$ reaction mixture consisted of IX PCR reaction buffer (Promega), $200 \mu \mathrm{M}$ dNTPs and 0.5 units Taq polymerase. The PCR cycling parameters were: 30 cycles of denaturation at $95{ }^{\circ} \mathrm{C}$ for $30 \mathrm{~s}$, annealing at $54{ }^{\circ} \mathrm{C}$ for $90 \mathrm{~s}$ and extension at $72{ }^{\circ} \mathrm{C}$ for $90 \mathrm{~s}$, preceded by heating at $95{ }^{\circ} \mathrm{C}$ for $5 \mathrm{~min}$ and followed by a final extension at $72{ }^{\circ} \mathrm{C}$ for $6 \mathrm{~min}$. For amplification of the $16 \mathrm{~S}$ rRNA from blood samples from the field, elevated magnesium ion concentrations at an increment of $2.5,3.0$ and $3.5 \mathrm{mM}$ and a primer concentration of $1.0 \mu \mathrm{M}$ were used.
The PCR products of the bcsp and omp2 gene targets were electrophoresed on $1.5 \%$ agarose while the amplicons from the $16 \mathrm{~S}$ rRNA gene targets were electrophoresed on a $2 \%$ agarose gel, stained with ethidium bromide and visualized under UV light.

Comparison of results and statistical analysis. Comparisons were made within the results of: (1) the three different PCRs on reference and 19 field isolates of Brucella; (2) the blood/serum ELISA and the PCR based on the bcsp/omp2 gene on blood from 87 field samples; (3) the consensus of blood PCR based on the bcsp and omp2 gene with the antibody detection ELISA on 62 blood samples from field. The overall proportion of agreement (OPA) and the proportion of agreement beyond chance $(\kappa$ value) between different blood PCR protocols and antibody detection ELISA were analysed employing the software WinEpiscope 1.0 (EPIDECON) at $95 \%$ confidence intervals.

\section{RESULTS AND DISCUSSION}

Although serological tests are the major diagnostic tools for screening of animal brucellosis in the field, they are neither fully sensitive nor specific due to insufficient immunity or serological cross-reactivity. Bacteriological isolation of Brucella on the other hand is regarded, because of its specificity, as the gold standard for diagnosis. Since this procedure is laborious for large-scale diagnosis and since detection of specific DNA is a true indication of the presence of a pathogen, we wanted to compare the applicability of different established PCRs against serology for rapid, sensitive and specific detection of Brucella in animals from a large population under endemic situations. Few reports have described the application of diagnostic PCR on field samples (Amin et al., 2001; Fekete et al., 1992; Romero et al., 1995b; Sreevatsan et al., 2000) and there are no studies correlating results of PCR from multiple gene targets with those of serological diagnosis.

The study was designed in two components: (1) evaluation of the specificity of the genus-specific $b c s p$ PCR and its comparison with other established diagnostic PCRs on the omp2 (Leal-Klevezas et al., 1995) and 16S rRNA (Romero et al., 1995b) genes using standard Brucella strains, serologically related non-Brucella organisms as well as Brucella isolates from human and bovine infections; (2) PCR with confirmed specificity was then used as a positive indicator of infection to screen bovine blood samples from sero-positive herds and compare with ELISA.

\section{Amplification of bcsp, omp2 and the 16S rRNA from reference strains and Indian field strains}

The three independent PCR assays resulted in the amplification of 223, 193 and 905 bp amplicons, respectively, from the $b c s p$, omp2 and 16S rRNA gene PCRs from all six Brucella reference strains but not from other serologically related strains (Table 1). All PCRs were repeated twice. All the three categories of PCR products from the field isolates were confirmed for specificity by Southern hybridizations using non-radioactive probes prepared by labelling of corresponding amplicons from 
standard strains (data not shown). The 905 bp amplicon from the 16S rRNA gene in the Brucella reference strain was obtained after modification of the protocol of Romero et al. (1995b) by changing the $\mathrm{Mg}^{2+}$ concentration from the recommended $1.0 \mathrm{mM}$ to $1.5 \mathrm{mM}$ and the annealing temperature from 54 to $50{ }^{\circ} \mathrm{C}$.

All 19 Indian field strains were identified as belonging to the genus Brucella by the PCR assays based on both bcsp and the omp2 gene (Fig. 1). These were therefore concluded as specific for Brucella and taken further for analysis of blood samples. However, 16S rRNA gene specific amplification was obtained only in 14 of the 19 isolates. Of the 19, 7 were bovine milk isolates of which only 2 were identified as Brucella by the 16S rRNA PCR (Fig. 2).

Isolation of $B$. abortus biovars $1,3,4,6$ and 9, B. melitensis biovars 1, 2 and 3, B. suis biovar 1 and B. canis has been reported from India (Sen \& Sharma, 1975) and there is enough evidence from previous work by others (LealKlevezas et al., 1995; Romero et al., 1995b; Da Costa et al., 1996; Sifuentes-Rincon et al., 1997; Lopez-Goni, 2001; Bricker, 2002; Probert et al., 2004) that PCR assays based on bcsp, omp2 and the $16 \mathrm{~S}$ rRNA are able to detect all species and biovars of the genus Brucella. However, even
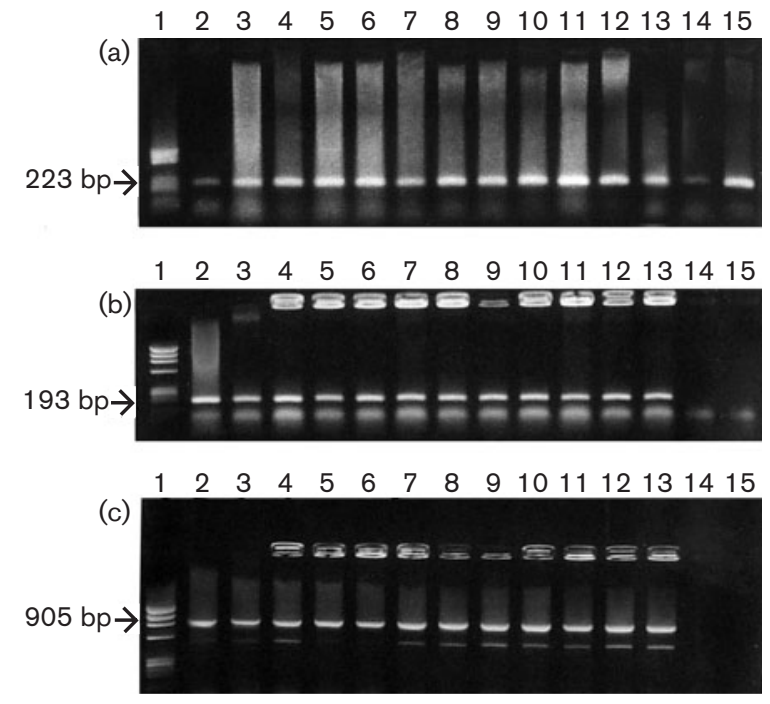

Fig. 1. Brucella-specific BCSP $31 \mathrm{kDa}$ gene (Baily et al., 1992) (a), omp2 (Leal-Klevezas et al., 1995) (b) and 16S rRNA gene (Romero et al., 1995b) (c) PCRs on isolates from field cattle from the Indian Veterinary Research Institute (IVRI), Izzatnagar. Lanes: 1, DNA molecular size markers [marker $\mathrm{V}$ (Boehringer Mannheim) in (a); phiX174 Haell digest (Promega) in (b) and (c)]; 2 and 3, Brucella abortus 544 (ATCC) and Brucella melitensis (ATCC), respectively; 4-13, human and bovine isolates from IVRI (10/98, 24/97, 3/97, 5/97, 20/97,6/86, 5/98, 25/97 and 7/97, respectively); 14 and $15, B$. abortus isolates from mice liver and genital tissue (a) and $M$. tuberculosis H37Rv and water (b, c). Ten microlitres of amplicon was separated by electrophoresis, treated with ethidium bromide, and visualized under UV light. with modifications only two out of seven bovine milk isolates yielded 16S rRNA PCR products. All Brucella 16S rRNA gene sequences have been reported to be identical (Gee et al., 2004). However, our subsequent multiple alignment analysis of $16 \mathrm{~S}$ rRNA sequences of various Brucella spp. to the primers used (Romero et al., 1995a) showed alignment of the primer F4 with $100 \%$ identity to the sequence of a single B. abortus (Dorsch et al., 1989; accession no. X13695), while with other species and other B. abortus-like sequence (Gee et al., 2004), alignment was seen only for the first 10 of the 17 nucleotides in the primer owing to the presence of an additional base ' $C$ ' in these strains that was absent in the said B. abortus (Fig. 3). This lack of alignment beyond $10 \mathrm{bp}$ would have resulted in defective annealing at the temperature used yielding no PCR products. The reverse primer too showed an identity of $18 / 20$ for strains other than B. abortus. These do not, however, explain why the standard strains yielded expected PCR products albeit at a lower annealing temperature than
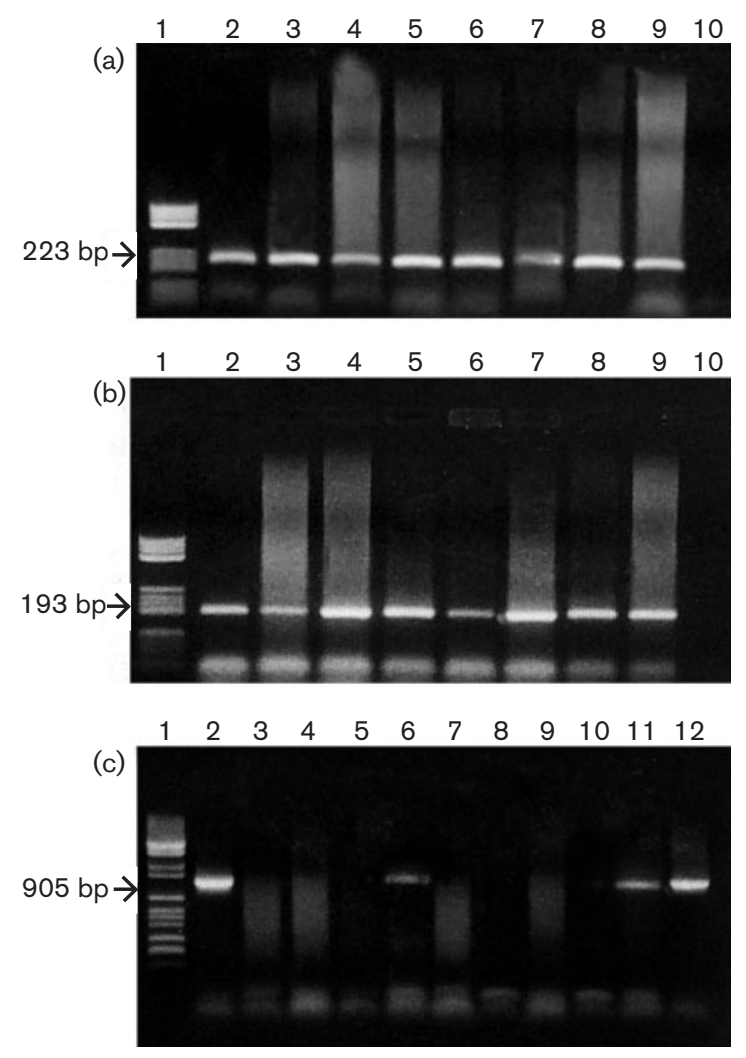

Fig. 2. Brucella-specific $P C R$ on isolates from bovine milk. (a) BCSP 31 kDa PCR; (b) omp2 PCR; (c) 16S rRNA PCR. Lanes: 1, DNA molecular size markers [marker $V$ (Boehringer Mannheim) in (a); phiX174 Haelll digest (Promega) in (b) and (c)]; 2, Brucella abortus 544 (ATCC); 3-9, isolates from bovine milk; 10, water control; 11 and 12 in (c), B. abortus isolates from mice liver and genital tissue. Ten microlitres of amplicon was separated by electrophoresis, treated with ethidium bromide, and visualized under UV light. 
(a)

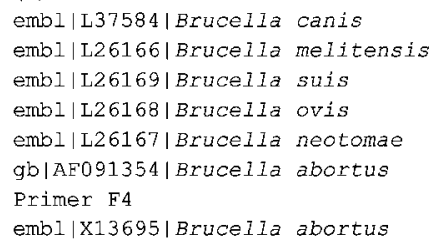

(b)

embl|L37584|Brucella canis

embl|L26166| Brucella melitensis

embl|L26169|Brucella sius

embl|L26168|Brucella ovis

embl | L26167| Brucella neotomae

gb|AF091354|Brucella abortus

Primer R2

embl|X13695|Brucella abortus
AACACATGCAAGTCGAGCGCCCCGCAAGGG-GAGCGGCAGACGGGTGAGTA 76 AACACATGCAAGTCGAGCGCCCCGCAAGGG-GAGCGGCAGACGGGTGAGTA 70 AANACATGCAAGTCGAGCGCCCCGCAAGGG-GAGCGGNAGACGGGTGAGTA 77 AACACATGCAAGTCGAGCGCCCCGCAAGGG-GAGCGGCAGACGGGTGAGTA 77 AACACATGGAAGTCGAGCGCCCCGCAAGGG-GAGCGGAAGACGGGTGAGTA 77 AACACATGCAAGTCGAGCGCCCCGCAAGGG-GAGCGGCAGACGGGTGAGTA 77

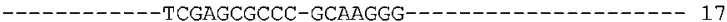
AACACATGCAACTCGAGCGCCC-GCAAGGGTGAGCGGCAGACGGGTGAGTA 100

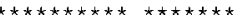

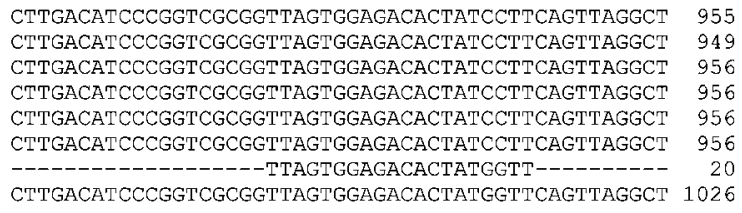

CTTGACATCCCGGTCGCGGTTAGTGGAGACACTATCCTTCAGTTAGGCT 955 CTTGACATCCCGGTCGCGGTTAGTGGAGACACTATCCTTCAGTTAGGCT 949 CTTGACATCCCGGTCGCGGTTAGTGGAGACACTATCCTTCAGTTAGGCT 956 CTTGACATCCCGGTCGCGGTTAGTGGAGACACTATCCTTCAGTTAGGCT 956 CTTGACATCCCGGTCGCGGTTAGTGGAGACACTATCCTTCAGTTAGGCT 956 CITGACATCCCGGTCGCGETIAGTGGAGACACTATCCTTCAGTTAGGCT 956 -----------------TTAGTGGAGACACTATGGTT---------- 20 CTTGACATCCCGGTCGCGGTTAGTGGAGACACTATGGTTCAGTTAGGCT 1026

Fig. 3. Multiple alignment of $16 \mathrm{~S}$ rRNA sequences of various Brucella spp. indicating differences between $B$. abortus (X13695) and other Brucella spp. in sequence conservation corresponding to the forward primer F4 (a) and reverse primer R2 (b) used for PCR as per Romero et al. (1995a). The source, accession number and strain name for each sequence are indicated on the left.

recommended. A new primer that is fully and specifically conserved in all Brucella species is required for genusspecific 16S rRNA PCR. In a study using 16S rRNA target (Lopez-Goni, 2001), milk culture and PCR results have been negatively correlated with each other where 26 out of $31 \mathrm{~B}$. melitensis biovar 3 isolates (from bovine milk) could be identified as Brucella.

\section{Results of 165 rRNA PCR on blood samples}

Although $\mathrm{Mg}^{2+}$ was elevated and the primer concentration increased to $1 \mu \mathrm{M}$, the 905 bp specific amplicon could not be detected directly from any of the blood samples tested on repeated attempts under various PCR conditions, probably owing to the reasons described above. Hence the 16S rRNA was not used for comparison with bcsp and omp2 PCRs. The sensitivity of $16 \mathrm{~S}$ rRNA primers has been previously reported to be affected by the presence of human DNA (Navarro et al., 2002).

\section{Correlation studies between bcsp and omp2 gene based blood PCR on field samples}

The observed proportion of agreement $(\mathrm{OPA}=0.71$ at $P$ $<0.05)$ was good and the degree of association $(\kappa=0.45$ at $P<0.05)$ was moderate between the two diagnostic blood PCR assays. The two PCR assays disagreed in $28.7 \%$ of cases (Table 2). The bcsp was more sensitive as it could detect $24 \%$ more samples $(21 / 87)$ as positive than omp2. Such a difference was not seen in PCR carried out on bacterial isolates. The present studies seemed to indicate that the presence of host DNA could affect the sensitivity of primers for the detection of Brucella in bovine blood as observed previously (Navarro et al., 2002). The sensitivity of the detection system could also be affected by modification of the original blood PCR protocol (Romero et al., 1995a, b; Leal-Klevezas et al., 1995) in our hands. Finally it cannot be ruled out that the bcsp gene sequence is better conserved than the omp2 sequence in the genus Brucella. Variation in the omp2 sequence has been used as a basis for typing strains (Bardenstein et al., 2002; Ferrao-Beck et al., 2006).

\section{Correlation studies between antibody-detecting ELISA and blood PCRs}

ELISA versus bcsp PCR. Correlation studies on 87 bovine/buffalo blood samples from the field showed that although the overall proportion of agreement between the two tests $(0.66$ at $P<0.05)$ was strong, the degree of association was weak $(\kappa=0.34$ at $P<0.05)$ (Table 2$)$. The PCR could detect $20.6 \%$ more blood samples as positive compared to ELISA. Brucella genus specific sequence signatures were detected from $47 \%$ (24/51) of serologically negative animals. Also this PCR was unable to detect Brucella in $6.8 \%(6 / 87)$ of samples that were ELISA-positive.

Increased sensitivity of BCSP PCR over serology has been observed by Queipo-Ortuno et al. (2006), where seroagglutination was inconclusive in $30 \%$ of cases whereas realtime PCR assay was positive in $90 \%$ of samples of human brucellosis.

ELISA versus omp2-based PCR. The omp2 gene could be amplified from blood samples by a modified PCR protocol. The $193 \mathrm{bp}$ amplicon was obtained only after increasing the concentration of $\mathrm{Mg}^{2+}$ from 3.0 to $4.0 \mathrm{mM}$ and that of the primers from 50 to $100 \mathrm{pmol}$ in the reaction. The overall proportion of agreement $(\mathrm{OPA}=0.70$ at $P<0.05)$ and the degree of association $(\kappa=0.38$ at $P<0.05)$ between 
Table 2. Correlation of blood PCRs and their comparison with antibody-detecting ELISA

\begin{tabular}{|c|c|c|c|c|}
\hline Blood PCRs & BCSP-positive & BCSP-negative & Total & $\begin{array}{l}\text { OPA and proportion } \\
\text { of agreement beyond } \\
\text { chance }(\kappa \text { value })^{\star}\end{array}$ \\
\hline Omp2+ & 30 & 4 & 34 & $\mathrm{OPA}=0.71, \kappa=0.45$ \\
\hline Omp2- & 21 & 32 & 53 & \\
\hline Total & 51 & 36 & 87 & \\
\hline $\begin{array}{l}\text { ELISA versus } \\
\text { BCSP/Omp2 } \\
\text { PCRs }\end{array}$ & ELISA-positive & ELISA-negative & & \\
\hline $\mathrm{BCSP}+$ & 30 & 24 & 54 & \\
\hline BCSP- & 6 & 27 & 33 & $\mathrm{OPA}=0.66, \kappa=0.34$ \\
\hline Total & 36 & 51 & 87 & \\
\hline Omp2+ & 21 & 11 & 32 & \\
\hline Omp2- & 15 & 40 & 55 & $\mathrm{OPA}=0.70, \kappa=0.38$ \\
\hline Total & 36 & 51 & 87 & \\
\hline $\mathrm{BCSP}+\mathrm{Omp} 2+$ & 20 & 10 & 30 & \\
\hline BCSP- Omp2- & 6 & 26 & 32 & $\mathrm{OPA}=0.74, \kappa=0.5$ \\
\hline Total & 26 & 36 & 62 & \\
\hline
\end{tabular}

* Statistical features were calculated from category-wise comparison of test results employing WinEpiscope 1 software (EPIDECON) with a $95 \%$ confidence level.

the two tests were similar to those in ELISA versus $b c s p$ PCR (Table 2). The ELISA identified $41.4 \%(36 / 87)$ of samples as positive for brucellosis; in comparison, the omp2 blood PCR detected Brucella in 38\% (32/87) of samples. From serologically negative samples $21.6 \%$ (11/51) were PCR-positive while $17.2 \%(15 / 87)$ of ELISA-positive samples yielded negative results for omp2 blood PCR.

omp2-based PCR has been used previously (Leal-Klevezas et al., 1995) for identification of Brucella from blood of naturally infected caprines where $86.3 \%$ (19/22) were identified as positive by PCR in comparison to $63.6 \%$ (14/ 22) by serology. The reduced sensitivity of the omp2 PCR against ELISA on blood samples might be a mere reflection of the high immune response in the bovine system as compared to the caprine system.

ELISA versus consensus of PCR based on bcsp and omp2. Only 62 out of 87 samples were screened by ELISA and $b c s p$ and omp2 PCR. The consensus data of the $b c s p$ and omp2 blood PCR showed the best overall proportion of agreement $(\mathrm{OPA}=0.74$ at $P<0.05)$ and a fair improvement in the degree of association $(\kappa=0.5$ at $P$ $<0.05$ ) with ELISA as compared to ELISA versus $b c s p$ or ELISA versus omp2-based PCR (Table 2). The consensus of two PCRs identified $6 \%$ more samples $(30 / 62)$ than ELISA (26/62) as positive and detected Brucella infection in $27.7 \%$ (10/36) of animals that were serologically negative, but eliminated $9.7 \%(6 / 62)$ animals that were ELISA-positive.
In the absence of the availability of an antigen-detecting ELISA we had used the antibody detection ELISA, widely used for serological monitoring programmes in India, despite the fact that antibody status did not always indicate disease under the chronic endemic situation that exists in the country. Evidence from human brucellosis indicates that the expression of anti-brucella antibodies does not correlate with the status of the disease (Elfaki et al., 2005). Therefore, we wanted to study how the degree of association ( $\kappa$ value) between two tests systems was affected when the diagnostic gene targets in the PCR assays were altered. As observed in this study, the change in the gene target did not affect the nature or degree of association between ELISA and blood PCR. However, the closest and the best degree of statistical association $(\kappa=0.5$ at $P<0.05)$ was achieved when consensus results of $b c s p$ and omp2 PCR were compared with those from ELISA. Therefore, we believe that consensus PCR is a more reliable diagnostic approach.

In an overall analysis of differential detection rates by ELISA and the two blood PCRs, the bcsp PCR was the most sensitive $(92.72 \%)$ followed by omp2 PCR (61.81\%) and ELISA (55.55\%). These values were calculated taking into consideration that, in the absence of pathogen isolation, a positive PCR for $b c s p$ or omp2 from the blood samples was regarded as a true indication of infection, as their specificities were confirmed by the PCRs on field isolates. Thus $b c s p$ and omp2 PCRs together indicated 55 true infections (Table 2), wherein bcsp showed maximum 
sensitivity (51/55). This assumption did not permit any consideration of false positive by PCR. Moreover, neither PCR gave false positives with non-brucella cultures. Thus both PCRs exhibited a specificity and positive predictive value of $100 \%$ while ELISA showed $81.8 \%$ specificity and $83.3 \%$ positive predictive value. $b c s p$ PCR also gave a higher negative predictive value $(88.88 \%)$ than the omp2 PCR (61.81\%) and ELISA (55.55\%). Since anti-brucella antibodies do not always indicate disease, evaluation of ELISA was done using bcsp PCR results as a reference (Table 2). ELISA was positive for 30 out of 54 bcsp-positive samples, making it the least sensitive test. The consensus of PCRs detected $6 \%$ more samples as positive than ELISA and perhaps it should be considered most specific, as it seemed to be neither under- nor over-detecting Brucella infection. The consensus of PCRs also seemed to show a low degree of failure since it was unable to detect infection on $9.7 \%$ of occasions from ELISA-positive animals. Compared to the PCR consensus the omp2 system failed on $17.2 \%$ occasions. The most favourable factor regarding the omp2 PCR was that it had the best agreement of $78 \%(40 / 51)$ with the ELISA-negative samples in comparison to other PCR systems. We finally conclude that the use of more than one marker-based PCR gave increased sensitivity and higher specificity and appears to be a more reliable molecular diagnostic approach for screening of field animals.

\section{ACKNOWLEDGEMENTS}

This work was supported by funds kindly provided by the National Dairy Development Board, Anand, under a collaborative research project between the National Dairy Development Board and the Department of Microbiology and Biotechnology Centre, M. S. University, Baroda. We want to thank Dr G. K. Sharma from the National Dairy Development Board for providing Brucella isolates from bovine milk samples from the field and Mrs S. A. Patel for maintenance and propagation of these strains and for performance of Brucella antibody detection ELISA on serum samples from the field.

\section{REFERENCES}

Alton, G. G., Jones, L. M., Angus, R. D. \& Verger, J. M. (1988). Techniques for the Brucellosis Laboratory. Paris: Institute National De La Recherche Agronomique.

Amin, A. S., Hamdy, M. E. \& Ibrahim, A. K. (2001). Detection of Brucella melitensis in semen using the polymerase chain reaction assay. Vet Microbiol 83, 37-44.

Ariza, J., Pellicer, T., Pallares, R., Foz, A. \& Gudiol, F. (1992). Specific antibody profile in human brucellosis. Clin Infect Dis 14, 131-140.

Baily, G. G., Krahn, J. B., Drasar, B. S. \& Stoker, N. G. (1992). Detection of Brucella melitensis and Brucella abortus by DNA amplification. J Trop Med Hyg 95, 271-275.

Bardenstein, S., Mandelboim, M., Ficht, T. A., Baum, M. \& Banai, M. (2002). Identification of the Brucella melitensis vaccine strain Rev.1 in animals and humans in Israel by PCR analysis of the PstI site polymorphism of its omp2 gene. J Clin Microbiol 40, 1475-1480.

Baumann, P., Furniss, A. L. \& Lee, J. V. (1984). Genus I Vibrio Pancini. In Bergey's Manual of Systematic Bacteriology, vol. 1, pp. 518-538. Edited by N. R. Krieg \& J. G. Holt. Baltimore. Williams \& Wilkins.

Bogdanovich, T., Skurnik, M., Lubeck, P. S., Ahrens, P. \& Hoorfar, J. (2004). Validated $5^{\prime}$ nuclease PCR assay for rapid identification of the genus Brucella. J Clin Microbiol 42, 2261-2263.

Bricker, B. J. (2002). PCR as a diagnostic tool for brucellosis. Vet Microbiol 90, 435-446.

Bricker, B. J. \& Ewalt, D. R. (2006). HOOF prints: Brucella strain typing by PCR amplification of multilocus tandem-repeat polymorphisms. Methods Mol Biol 345, 141-173.

Bricker, B. J., Tabatabai, L. B., Deyoe, B. L. \& Mayfield, J. A. (1988). Conservation of antigenicity in a $31 \mathrm{kDa}$ Brucella protein. Vet Microbiol 18, 313-325.

Corbel, M. J. (1997). Brucellosis: an overview. Emerg Infect Dis 3, 213-221.

Corbel, M. J. \& Brinley-Morgan, W. J. (1984). Genus Brucella Meyer and Shaw 1920, 173. In Bergey's Manual of Systematic Bacteriology, vol. 1, pp. 377-388. Edited by N. R. Krieg \& J. G. Holt. Baltimore: Williams \& Wilkins.

Cousins, D. V., Williams, S. N., Ross, B. C. \& Ellis, T. M. (1993). Use of a repetitive element isolated from Mycobacterium tuberculosis in hybridization studies with Mycobacterium bovis: a new tool for epidemiological studies for bovine tuberculosis. Vet Microbiol 37, $1-17$.

Da Costa, M., Guillou, J. P., Garin-Bastuji, B., Theibaud, M. \& Dubray, G. (1996). Specificity of six gene sequences for the detection of the genus Brucella by DNA amplification. J Appl Bacteriol 81, 267-275.

Dorsch, M., Moreno, E. \& Stackebrandt, E. (1989). Nucleotide sequence of the 16S rRNA from Brucella abortus. Nucleic Acids Res 17, 1765.

Elfaki, M. G., Uz-Zaman, T., Al-Hokail, A. A. \& Nakeeb, S. M. (2005). Detection of Brucella DNA in sera from patients with brucellosis by polymerase chain reaction. Diagn Microbiol Infect Dis 53, 1-7.

Ewalt, D. R. \& Bricker, B. J. (2000). Validation of the abbreviated Brucella AMOS PCR as a rapid screening method for differentiation of Brucella abortus field strain isolates and the vaccine strains, 19 and RB51. J Clin Microbiol 38, 3085-3086.

Fekete, A., Bantle, J. A. \& Halling, S. M. (1992). Detection of Brucella by polymerase chain reaction in bovine fetal and maternal tissues. J Vet Diagn Invest 4, 79-83.

Ferrao-Beck, L., Cardoso, R., Munoz, P. M., de Miguel, M. J., Albert, D., Ferreira, A. C., Marin, C. M., Thiebaud, M., Jacques, I. \& other authors (2006). Development of a multiplex PCR assay for polymorphism analysis of Brucella suis biovars causing brucellosis in swine. Vet Microbiol 115, 269-277.

Fitch, T. A., Bearden, S. W., Sowa, B. A. \& Adams, L. G. (1989). DNA sequence and expression of the 36 kilo-dalton outer membrane protein gene of Brucella abortus. Infect Immun 57, 3281-3291.

Gee, J. E., De, B. K., Levett, P. N., Whitney, A. M., Novak, R. T. \& Popovic, T. (2004). Use of $16 \mathrm{~S}$ rRNA gene sequencing for rapid confirmatory identification of Brucella isolates. J Clin Microbiol 42, 3649-3654.

Godfroid, J., Saegerman, C., Wellemans, V., Walravens, K., Letesson, J. J., Tibor, A., McMillan, A., Spencer, S., Sanna, M. \& other authors (2002). How to substantiate eradication of bovine brucellosis when aspecific serological reactions occur in the course of brucellosis testing. Vet Microbiol 90, 461-477.

Le Fleche, P., Jacques, I., Grayon, M., Al Dahouk, S., Bouchon, P., Denoeud, F., Nockler, K., Neubauer, H., Guilloteau, L. A. \& Vergnaud, G. (2006). Evaluation and selection of tandem repeat loci for a Brucella MLVA typing assay. BMC Microbiol 6, 9. 
Leal-Klevezas, D. S., Martinez-Vaquez, I. O., Lopez-Merino, A. \& Martinez-Soriano, J. P. (1995). Single-step PCR for detection of Brucella spp. from blood and milk of infected animals. J Clin Microbiol 33, 3087-3090.

Leyla, G., Kadri, G. \& Umran, O. (2003). Comparison of polymerase chain reaction and bacteriological culture for the diagnosis of sheep brucellosis using aborted fetus samples. Vet Microbiol 93, 53-61.

Lopez-Goni, I. (2001). Detection of Brucella by PCR: application limits and needs. In Brucellosis in Animals and Man. Proceedings of the Combined COST Meeting for Working Groups 1 (Epidemiology), Pamplona, Spain June 11-12, 2001. Progress Report of Action 845: Food \& Agriculture Domain. Brussels: European Cooperation in the Field of Scientific and Technical Research (COST).

Lulu, A. R., Araz, G. F., Khatib, M. I., Mustafa, M. Y., Yusuf, A. R. \& Fenech, F. F. (1988). Human brucellosis in Kuwait: a prospective study of 400 cases. Q J Med 66, 39-54.

Marianelli, C., Ciuchini, F., Tarantino, M., Pasquali, P. \& Adone, R. (2006). Molecular characterization of the $r p o B$ gene in Brucella species: new potential molecular markers for genotyping. Microbes Infect 8, 860-865.

Mayfield, J. E., Bricker, B. J., Godfrey, H., Crosby, R. M., Knight, D. J., Halling, S. M., Balinsky, D. \& Tabataba, L. B. (1988). The cloning, expression, and nucleotide sequence of the BCSP 31 gene from Brucella abortus. Gene 63, 1-9.

Morata, P., Quiepo-Ortuno, M. I., Reguera, J. M., Garcia-Ordonez, M. A., Ca'rdenas, A., Juan, D. \& Colmenero, J. D. (2003). Development and evaluation of a PCR-enzyme-linked immunosorbent assay for diagnosis of human brucellosis. J Clin Microbiol 41, 144-148.

Mukherjee, F., Jain, J., Grillo, M. J., Blasco, J. M. \& Nair, M. (2005). Evaluation of Brucella abortus S19 vaccine strains by bacteriological tests, molecular analysis of ery loci and virulence in $\mathrm{BALB} / \mathrm{c}$ mice. Biologicals 33, 153-160.

Navarro, E., Escribano, J., Fernández, J. A. \& Solera, J. (2002). Comparison of three different PCR methods for detection of Brucella spp in human blood samples. FEMS Immunol Med Microbiol 34, 147-151.

Navarro, E., Segura, J. C., Castaño, M. J. \& Solera, J. (2006). Use of real-time quantitative polymerase chain reaction to monitor the evolution of Brucella melitensis DNA load during therapy and posttherapy follow-up in patients with brucellosis. Clin Infect Dis 42, 1266-1273.

Nicoletti, P. (1980). The epidemiology of bovine brucellosis. Adv Vet Sci Comp Med 24, 69-89.

O'Leary, S., Sheahan, M. \& Sweeney, T. (2006). Brucella abortus detection by PCR assay in blood, milk and lymph tissue of serologically positive cows. Res Vet Sci 81, 170-176.

OIE (1996). WHO, Manual of Standards for Diagnostic Tests and Vaccine, 3rd edn, chapter 3.2.1, pp. 242-255. Paris: Office International des Epizootics.
Probert, W. S., Schrader, K. N., Khuong, N. Y., Bystrom, S. L. \& Graves, M. H. (2004). Real-time multiplex PCR assay for detection of Brucella spp., B. abortus, and B. melitensis. J Clin Microbiol 42, 1290-1293.

Queipo-Ortuno, M. I., Colmenero, J. D., Reguera, J. M., GarciaOrdonez, M. A., Pachon, M. E., Gonzalez, M. \& Morata, P. (2005). Rapid diagnosis of human brucellosis by SYBR Green I-based realtime PCR assay and melting curve analysis in serum samples. Clin Microbiol Infect 11, 713-718.

Queipo-Ortuno, M. I., Morata, P., Ocon, P., Manchado, P. \& de Dios Colmenero, J. (2006). Rapid diagnosis of Brucella epididymo-orchitis by real-time polymerase chain reaction assay in urine samples. J Urol 176, 2290-2293.

Radostits, O. M., Blood, D. C. \& Gay, C. C. (editors) (1994), Veterinary Medicine. A Text Book of the Diseases of Cattle, Sheep, Pigs, Goats and Horses, 8th edn, pp. 789-812. London: Baillière Tindall.

Redkar, R., Rose, S., Bricker, B. \& DelVecchio, V. (2001). Real-time detection of Brucella abortus, Brucella melitensis, and Brucella suis. Mol Cell Probes 15, 43-52.

Rijpens, N. P., Jannes, G., Asbroeck, M. V., Rossau, R. \& Herman, L. M. F. (1996). Direct detection of Brucella spp. in raw milk by PCR and reverse hybridization with 16S-23S rRNA spacer probes. Appl Environ Microbiol 62, 1683-1688.

Romero, C., Gamazo, C., Pardo, M. \& López-Goñi, I. (1995a). Specific detection of Brucella DNA by PCR. J Clin Microbiol 33, 615-617.

Romero, C. M., Padro, M., Grillo, M. J., Diaz, R., Blasco, J. M. \& LopezGoni, I. (1995b). Evaluation of PCR and indirect enzyme-linked immunosorbent assay on milk samples for diagnosis of brucellosis in cattle. J Clin Microbiol 33, 3198-3200.

Sen, G. P. \& Sharma, G. L. (1975). Speciation of seventy-eight Indian strains of Brucella: an epidemiological study. Indian J Anim Sci 45, 537-542.

Sifuentes-Rincon, A. M., Revol, A. \& Barrera-Saldana, H. A. (1997). Detection and differentiation of the six Brucella species by polymerase chain reaction. Mol Med 3, 734-739.

Sreevatsan, S., Bookout, J. B., Ringpis, F., Perumaalla, V. S., Fitch, T. A., Adams, L. G., Haguis, S. D., Elzer, P. H., Bricker, B. J. \& other authors (2000). A multiplex approach to molecular detection of Brucella abortus and/or Mycobacterium bovis infection in cattle. J Clin Microbiol 38, 2602-2610.

Weynants, V., Tibor, A., Denoel, P. A., Saegerman, C., Godfroid, J., Thiange, P. \& Letesson, J. J. (1996). Infection of cattle with Yersinia enterocolitica $\mathrm{O}: 9$ a cause of the false positive serological reactions in bovine brucellosis diagnostic tests. Vet Microbiol 48, 101-112.

Yagupsky, P. (1994). Detection of Brucella melitensis by BACTEC NR660 blood culture system. J Clin Microbiol 32, 1899-1901. 